\title{
Encapsulació i estructura informativa en el debat parlamentari. Una anàlisi contrastiva (català - espanyol - anglès)
}

\author{
Encapsulation and Information Structure \\ in Parliamentary Debate. \\ A Cross-linguistic Analysis (Catalan - Spanish - English)
}

\author{
Josep E. Ribera \\ Departament de Filologia Catalana, Universitat de València, Av. Blasco Ibáñez, 32, \\ 46010 València \\ e-mail: josep.ribera@uv.es
}

\begin{abstract}
Parliamentary debate (PD) as a specific genre of parliamentary discourse exhibits a hybrid nature: part oral and part written discourse. It is performed orally, but planned ahead and formal. From the point of view of lexical cohesion, encapsulation by means of abstract and unspecific nouns (e.g. fact or reason) is an indicator of the informative density and the underlying written nature of PD.

With the tools provided by Discourse Analysis and Cognitive Linguistics, this paper aims at describing and characterizing cross-linguistically lexical encapsulation's potential to define the information structure of PD. In this regard, encapsulation is analyzed in relation to the notions of topic and focus in three PDs in Catalan, Spanish and English. In order to determine the contribution of encapsulation to the information structure of $\mathrm{PD}$, we describe the properties of lexical encapsulation as a referential cohesion device and analyze the various lexico-grammatical and discourse patterns in which encapsulators occur. From a cross-linguistic point of view, the results show a higher frequency of encapsulation in the debate in English. In this respect, the Scottish debate exhibits a higher cohesive and informational density than the Catalan and the Spanish ones. However, there has also been observed a homogeneous crosslinguistic behavior of encapsulation with regard to weaving the information structure of PD. In fact, the different usage patterns uncover similar general trends in the three languages. These quantitative coincidences are interpreted as genre-related features. On the other hand, some patterns unveil cross-linguistic differences linked to a more speaker-dependent style aiming at guiding the addressee (persuasive function) and to the lexico-grammatical features of each language.
\end{abstract}

Keywords: encapsulation, lexical cohesion, topic, focus, information structure 


\section{INTRODUCCIÓ}

El debat parlamentari (d'ara endavant DP) constitueix un gènere del discurs polític caracteritzat per una dinàmica interactiva ritualitzada, però restringida. Es tracta d'un discurs híbrid entre l'oralitat i l'escriptura altament planificat i formal (van Dijk, 2000) l'objectiu del qual és escenificar la confrontació, tant individual com grupal, però també cercar la col·laboració, amb la intenció d'arribar a punts de trobada entre els participants (Cuenca, 2014).

Des del punt de vista dels mecanismes de cohesió lèxica (Halliday \& Hasan, 1976, pp. 275-292; Ribera, 2008, 2012), l'encapsulació (Schmid, 2000, entre altres) constitueix una evidència de la naturalesa escrita subjacent, de la planificació i de la densitat informativa (Jansen, 2000; Borreguero, 2006) del DP. Amb tot, no podem oblidar que l'escenificació oral del gènere requereix també l'explicitació de mecanismes cohesius que facilitin resseguir el fil del discurs. Vegem-ne un exemple:

(1) Esquerra Republicana està actuant d'una manera que aconseguirà que el seu mateix partit, els seus mateixos diputats i el seu mateix electorat tinguin una veritable OPA quan vostè no sigui capaç de dur a terme la consulta. Crec que és una estratègia intel·ligent, i és una estratègia en la qual vostè té un gran risc. (Investidura, SánchezCamacho, PP, 246)

En (1) podem observar que el substantiu estratègia encapsula, és a dir, reprèn anafòricament un fragment discursiu complex de naturalesa predicativa, en aquest cas, tota l'oració anterior.

L'objectiu d'aquest treball consisteix a caracteritzar i descriure contrastivament la contribució de l'encapsulació lèxica a l'estructura informativa del DP en català, espanyol i anglès. Així, amb les eines que ens proporciona l'anàlisi del discurs, en general, i l'estudi de l'estructura informativa, en concret, analitzem l'encapsulació lèxica com a mecanisme estructurador en tres debats, en català, en espanyol $i$ en anglès (un en cada llengua).

a. Català (Investidura): Sessió plenària d'Investidura del President de la Generalitat de Catalunya (X legislatura, primer període, sessió núm. 2), celebrada al Parlament de Catalunya els dies 20 i 21 de desembre de 2012.

b. Espanyol (Congreso): Sesión plenaria sobre la toma en consideración de la proposición de ley orgànica del Parlamento de Cataluña para la delegación en la Generalitat de la competencia para autorizar, convocar y celebrar un referéndum sobre el futuro político de Cataluña (X legislatura, núm. 192, sessió plenària núm. 180), celebrada al Congreso de los Diputados del Parlament Espanyol el 8 d'abril de 2014.

c. Anglès (Sct P): First Minister Statement on the Scottish Independence Referendum (The Scottish Parliament, 2013, pp. 18117-18132) / Debate on 
Scotland's Financial Strength (The Scottish Parliament, 2013, pp. 1813318183). Meeting of the Parliament, sessió núm 4, celebrada el 23 de març de 2013.

Per tal d'assolir l'objectiu esmentat, descrivim l'encapsulació lèxica com a mecanisme de cohesió referencial i n'analitzem qualitativament i quantitativament els patrons lexicogramaticals i discursius en què s'insereixen els noms encapsuladors, amb el propòsit de determinar-ne la contribució a l'estructura informativa del DP. A més, es descriuen els diferents efectes pragmaticodiscursius de cada patró i com es vinculen a la intenció argumentativa del debat.

Des del punt de vista contrastiu, els resultats mostren un comportament homogeni de la l'encapsulació en català, espanyol i anglès a l'hora d'entreteixir l'estructura del DP. De fet, els diferents patrons d'ús en què s'insereixen els encapsuladors mostren tendències quantitatives similars en les tres llengües. En aquest sentit, el recurs a l'encapsulació lèxica com a mecanisme estructurador del debat parlamentari emergeix com un tret interlingüístic vinculat al gènere. En altres paraules, el caràcter ritual i altament formalitzat del DP contribueix a homogeneïtzar-ne l'estructura informativa.

En resum, el nostre estudi palesa la importància de l'encapsulació com a mecanisme estructurador d'un gènere informativament dens com el DP. Específicament, el recurs a aquest mecanisme d'explicitació de l'estructura informativa del debat s'ha d'entendre com una estratègia a què recorre l'emissor per orientar el receptor al llarg del debat. Es tracta, doncs, d'una estratègia persuasiva essencial per a afavorir la dinàmica argumentativa del DP (Ribera \& Marín, en premsa).

\section{CARACTERÍSTIQUES DEL CORPUS}

Els tres debats del nostre corpus tenen en comú el tema general de discussió: s'ocupen directament o indirecta de la independència de Catalunya (en el cas del Parlament de Catalunya i del Congreso de los Diputados) i d'Escòcia (en el debat a The Scottish Parliament). L'elecció dels debats en funció del tema obeeix a dos motius:

a. Homogeneïtzar el corpus quant a l'assumpte del debat: atès que estem analitzant un procediment cohesiu que implica operacions semàntiques i cognitives de conceptualització i recategorització, cal controlar les variables que es podrien atribuir a l'assumpte dels debats stricto sensu.

b. L'assumpte de les independències respectives de Catalunya i Escòcia genera posicions polaritzades en els parlaments implicats i, per tant, permet comprovar com el repertori d'encapsuladors, més o menys extens, és el mateix en les tres llengües, amb independència de les posicions ideològiques que es defensin (Ribera \& Marín, en premsa). 
Cal tenir en compte una diferència substancial entre els debats català i espanyol, d'una banda, i el debat escocès i britànic, de l'altra. Els debats de l'àmbit hispànic s'estructuren a l'entorn d'una sèrie d'intervencions dels representants dels diversos grups parlamentaris sobre el tema del debat, sense possibilitat d'interrupció o interpel·lació in medias res per part dels oponents; en realitat, aquestes intervencions funcionen discursivament com una sèrie de monòlegs superposats. En canvi, en la tradició britànica, el debat que segueix la declaració ministerial o la presentació de la moció és molt més dialogat, malgrat la planificació de les intervencions, i els oradors es poden interrompre, demanant la paraula al diputat que està parlant (mitjançant la fórmula Will the member give way?), que té la potestat de cedir-la o no.

En el gràfic 1 es pot observar el contrast entre el nombre total de paraules de cada debat i el nombre d'encapsuladors identificats en el nostre corpus.

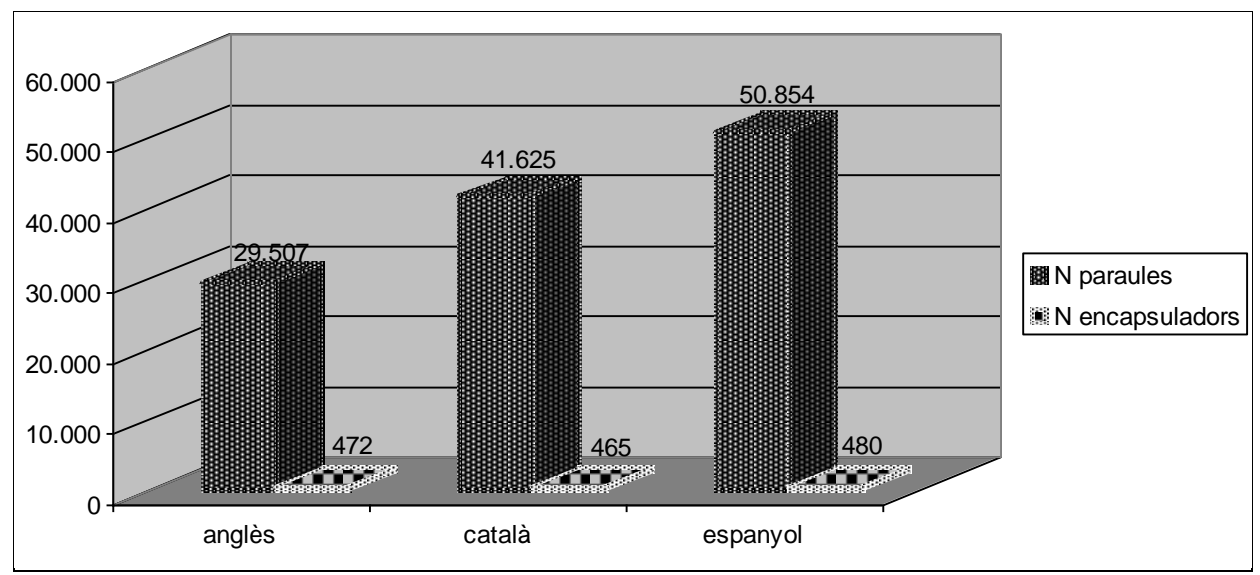

Gràfic 1. Nombre total de paraules vs. encapsuladors en el debat parlamentari

Aquestes dades generals, amb la freqüència relativa d'encapsuladors (\% sobre el nombre total de paraules del debat), es mostren en la taula $1 \mathrm{i}$ el gràfic 2 .

Taula 1. L'encapsulació en el debat parlamentari

\begin{tabular}{|l|l|l|l|}
\hline & Anglès & Català & Espanyol \\
\hline Núm. encapsuladors & 472 & 465 & 480 \\
\hline Freqüència relativa (\%) & 1,5996 & 1,1171 & 0,9439 \\
\hline Núm. total paraules & 29.507 & 41.625 & 50.854 \\
\hline
\end{tabular}


Les freqüències relatives dels encapsuladors en cada debat ofereixen un primer resultat destacable: el nombre d'encapsuladors és més elevat en el debat escocès que en l'espanyol i la freqüència en català se situa en un punt intermedi entre els altres dos. De fet, el gràfic 2 permet copsar que les freqüències relatives decreixen paulatinament entre l'anglès, el català i l'espanyol.

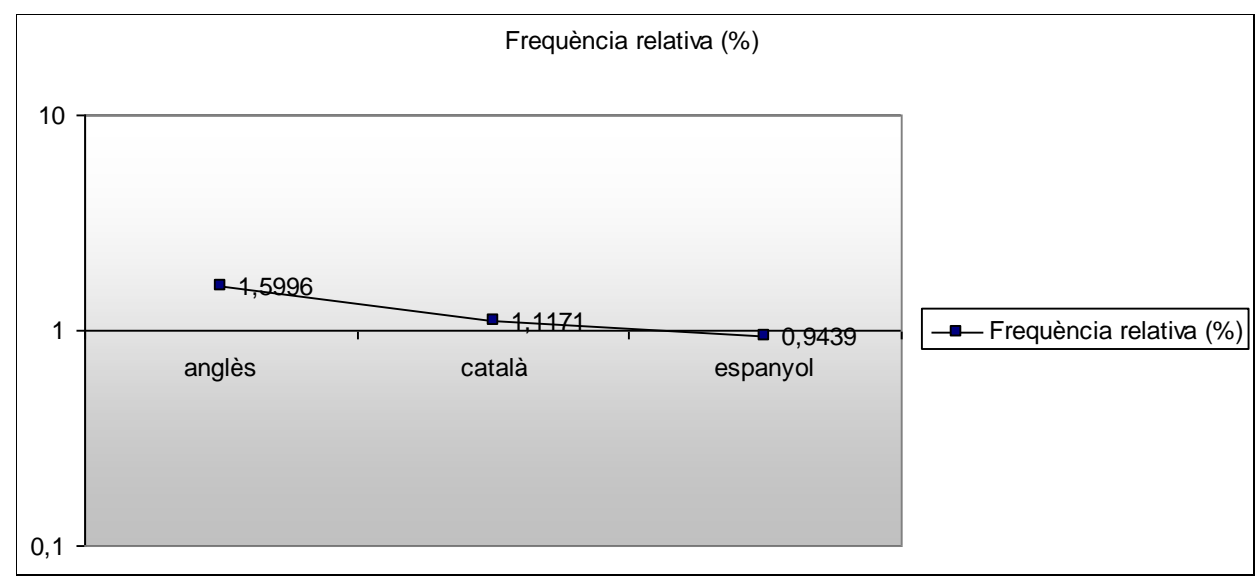

Gràfic 2. L'encapsulació en el debat parlamentari

Els tests estadístics revelen que, en efecte, hi ha una associació significativa entre les llengües i la proporció d'encapsuladors que presenten $\left(\chi^{2}(2)=71,023\right.$, $p<0,001)$. La magnitud de l'efecte quan es comparen les tres llengües, però, és petita ( $V$ de Cramer $=0,024)$, la qual cosa és previsible si tenim en compte que la diferència en percentatge és minsa considerant que es tracta d'una mostra bastant àmplia.

Els resultats dels tests també són significatius si es comparen les llengües de dos en dos: anglès $v s$. català $\left(\chi^{2}(1)=30,924, p<0,001, V\right.$ de Cramer $\left.=0,021\right)$; anglès $v s$. espanyol $\left(\chi^{2}(1)=68,589, p<0,001, V\right.$ de Cramer $\left.=0,029\right)$, i català $v s$. espanyol $\left(\chi^{2}(1)=6,792, p=0,009, V\right.$ de Cramer $\left.=0,009\right)$. Com es pot veure, l'efecte menor s'obté en la darrera comparació, cosa que pot suggerir que, atesa la relació filogenètica entre el català i l'espanyol i la semblança tipològica i estilística dels respectius DP, la diferència podria reduir-se $o$ fins $i$ tot desaparèixer en un corpus diferent.

Finalment, la comparació entre les dues llengües romàniques, considerades conjuntament, d'una banda, i l'anglès, de l'altra, es revela també significativa, amb una magnitud de l'efecte pràcticament idèntica a l'obtinguda en la comparació de les tres llengües per separat $\left(\chi^{2}(1)=65,040, p<0,001, V\right.$ de Cra- 
mer $=0,023$ ). De tot plegat, podem concloure que la densitat encapsuladora del debat escocès és superior a la dels debats en català $i$ en espanyol per separat $i$ en conjunt, mentre que la diferència entre el català i l'espanyol -clarament menor però estadísticament significativa- haurà de ser corroborada en estudis futurs.

Així doncs, si prenem l'encapsulació com un indicador de la densitat cohesiva, el debat en anglès mostra una major cohesió encapsuladora que el català i l'espanyol. D'altra banda, és fàcil assumir que un major grau de cohesió comporta una major densitat informativa (vg. les nocions d'estil cohesionat vs. segmentat en Serafini, 1992 i Cuenca, 2000). Aquest fet resulta evident en relació amb l'encapsulació, per la vinculació que manté amb la condensació informativa, l'estil nominalitzat i l'abstracció estilística (Schmid, 2000, pp. 70-73; Salvador, 2000).

Val a dir, en aquest sentit, que les freqüències relatives d'encapsuladors en els tres debats són més altes que la que proporciona López Samaniego (2011) per als seus editorials periodístics $(0,6 \%)$, considerats com a textos informativament densos (Jansen, 2000; Borreguero, 2006; López Samaniego, 2011, 2014). És ben clar, doncs, que el DP és informativament més dens ${ }^{1}$.

\section{EL DEBAT PARLAMENTARI COM A GÈNERE DEL DISCURS POLÍTIC}

D'acord amb van Dijk (2000), Illie (2006) i Cuenca (2014), el DP constitueix un gènere o subgènere específic del discurs polític que s'emmarca dins la categoria general del discurs públic oral. Van Dijk (2000, p. 47) explica que els gèneres del discurs polític no semblen exhibir característiques estructurals específiques i, doncs, tampoc no cal esperar-ne en el DP. Amb tot, des del nostre punt de vista, la freqüència de l'encapsulació, com a mecanisme cohesiu estructurador del DP, i dels patrons d'ús en què s'insereixen els encapsuladors constitueixen uns trets cohesius prominents d'aquest gènere del discurs polític, que haurien de ser presos en consideració en estudis futurs.

Van Dijk (2000, pp. 47-52) proposa que l'estudi del discurs polític, en general, i del DP, en concret -en tant que discursos definits bàsicament pel context-,

\footnotetext{
${ }^{1}$ D'acord amb Jansen (2000, p. 9), la densitat informativa es pot definir com "il rapporto fra la quantità di informazioni che il locutore intende veicolare con il suo testo e la quantità di materiale linguistico impiegata per veicolarle". Aquesta autora considera que hi ha tres variables que permeten mesurar la densitat informativa dels textos: a) la quantitat d'informació (explícita vs. implícita); b) els elements lingüístics informatius $v s$. els no informatius; i c) la qualitat de la informació, és a dir, el grau de cohesió (o "compattezza”, en paraules de Jansen, 2000) de la informació explícita. Els encapsuladors es vinculen a aquesta tercera variable.
} 
s'ha d'efectuar en relació amb algunes categories generals del context, que inclouen: a) el domini sociocognitiu o àmbit d'ús de la política, b) la tasca global que duu aparellada (fer política, governar, legislar), c) el caràcter institucionalitzat, d) l'esdeveniment comunicatiu que es produeix (debatre lleis, per exemple), e) el marc espaciotemporal en què es produeix la comunicació (la sessió del parlament), f) les activitats particulars i les interaccions entre els actors, g) els rols institucionalitzats dels actors, i h) el model cognitiu, que inclou el coneixement general de la situació i el coneixement compartit pels membres del parlament.

A partir d'aquest ancoratge contextual, van Dijk (2000) defineix prototípicament el DP com "a formal gathering of a group of elected representatives, members of various political parties, engaging in a discussion about what collective action or policy to undertake concerning an issue of public concern" (p. 53). De fet, aquest autor s'ocupa de remarcar a bastament que els únics trets discursius que inclou aquesta definició simple i planera (el mateix autor la qualifica com a "naive" i "lay definition") són la finalitat argumentativa ("discussion") $i$ els temes ("an issue of public concern").

Precisament, cal destacar el paper dels encapsuladors en relació amb la finalitat argumentativa. Com hem vist, el DP constitueix un tipus de discurs institucionalitzat (i, per tant, altament ritualitzat i formalitzat) que implica la interacció oral planificada i controlada dels participants, que fins i tot parlen amb la consciència que els seus discursos estan sent gravats i queden enregistrats (van Dijk, 2000, p. 52). Així, l'explicitació de la cohesió a través dels encapsuladors perfila l'estructura del debat i orienta el receptor destacant els assumptes que són objecte de discussió.

Des del punt de vista pragmàtic, Cuenca (2014) -seguint Illie (2006)- resumeix les característiques del debat parlamentari en la superposició de tres tipus de marcs institucionals (Cuenca, 2014, pp. 732-733):

a. El marc espaciotemporal: la interacció es produeix cara a cara i les intervencions tenen conseqüències en la comunitat política.

b. El marc dels participants: es refereix al rol polític que assumeixen els oradors, com a representants d'un partit o grup polític; en aquest sentit, s'adrecen no sols als altres participants en el debat, sinó també a la ciutadania en general i, sobretot, als votants.

c. El marc de la interacció entre els participants stricto sensu: la interacció entre els participants dóna compte de la superestructura textual, centrada en el tòpic general o assumpte del debat, i en els objectius que pretén aconseguir l'orador.

Òbviament, l'estructura informativa es vincula directament al marc dels participants $\mathrm{i}$ de la interacció que desenvolupen a través de la dinàmica argumentativa del debat, en què la cohesió i l'encapsulació és decisiva. 


\section{EL CONCEPTE D’ENCAPSULACIÓ}

D'acord amb Schmid (2000, pp. 10-20), els noms encapsuladors (shell nouns, en la terminologia de l'autor) constitueixen una classe funcional de noms abstractes i inespecífics que es caracteritzen perquè efectuen la represa anafòrica (o cataförica) de fragments textuals complexos de naturalesa predicativa. Observem-ho amb un exemple:

(2) Van ser capaços de repensar el sistema, de saber prioritzar allò que van considerar essencial, i van ser capaços de posar-se d'acord en com obtenir els ingressos suficients per mantenir-lo i, sobretot, per protegir-lo de manera que, independentment de la conjuntura econòmica externa, el nucli del sistema de benestar no es veiés afectat. Ara bé, què va fer possible l'aplicació d'aquelles mesures en qüestions tan sensibles com les polítiques socials en aquells països nòrdics? (Investidura, Mas, CiU, 111)

En (2) el substantiu mesures reprèn anafòricament, amb l'ajuda del demostratiu, el conjunt d'activitats expressades per les clàusules precedents. Observem que el procediment comporta tres conseqüències importants: a) semàntiques, b) pragmaticodiscursives i c) cognitives (Schmid, 2000, pp. 301-376; López Samaniego, 2014, pp. 39-53, 70-78):

a. Com a nom, mesures té un contingut lèxic estable que permet la caracterització semàntica de les clàusules precedents com a "mitjans proporcionats per aconseguir un fi'" (vg. mesura, DIEC2).

b. La inespecificitat semàntica del substantiu mesures el fa suficientment versàtil perquè pugui establir vincles funcionals de naturalesa cohesiva amb les clàusules encapsulades. De fet, la inespecificitat dels encapsuladors consisteix en l'existència de buits en l'estructura semàntica que s'han de saturar amb el contingut encapsulat. Observem com la definició de mesures que proporciona el diccionari s'efectua posant en relació un mitjà i un fi: es tracta d'una activitat tèl-lica, en què l'activitat específica ha de concretar-se, és a dir, relexicalitzar-se a través del discurs previ (Schmid, 2000, pp. 73-80).

c. El substantiu mesures recategoritza sintàcticament i cognitivament com a noms les clàusules represes, és a dir, reïfica aquest conjunt de predicats, d'entitats relacionals, i les conceptualitza, les perfila amb uns límits espaciotemporals estables, com si foren coses ("things", en el sentit de Langacker, 1987, p. 189). Així, els predicats reïficats poden ser represos en el discurs com a tòpics potencials. De fet, l'entitat referida per aquelles mesures en (2) constitueix el tòpic de l'oració interrogativa en què s'insereix.

En definitiva, aquestes tres propietats situen els noms encapsuladors en un punt d'equilibri entre els substantius lèxicament plens -amb un potencial de conceptualització constant, una capacitat de caracterització semàntica alta i una 
força cohesiva baixa- $\mathrm{i}$ els pronoms fòrics -incapaços de conceptualitzar i caracteritzar semànticament els antecedents, però prototípicament habilitats per efectuar funcions cohesives ${ }^{2}$.

\section{L'ESTRUCTURA INFORMATIVA. LES NOCIONS DE TÒPIC I FOCUS}

Tradicionalment, quan es parla d'estructura informativa, es fa referència a les nocions de tòpic, pressuposició o tema (com a informació coneguda), i focus, comentari o rema (com a informació nova que es predica sobre el tòpic).

D'acord amb Vallduví (2002, p. 1249), és possible distingir el tema del rema en funció de la contribució de la informació a l'estat epistèmic del receptor. Així, "les peces de significat proposicional que són identificades per l'emissor com a genuïnament informatives (per al receptor) formen el rema i les peces que tenen un valor informatiu nul són el tema o rerefons" (Vallduví, 2002, p. 1249).

Convé destacar, a partir de Givón (1983, pp. 5-7), que l'estudi del tòpic comença a tenir importància quan l'atenció dels estudis lingüístics supera els límits estructurals de l'oració i es dirigeix cap al discurs (Ribera, 2008, p. 158, nota 26). Givón (1983, p. 5) assenyala, com a precedents la tradició firthiana, els treballs de Bolinger $(1952,1954)$ sobre modificació lineal i l'obra de Firbas (1966a, 1966b), en l'àmbit de l'Escola de Praga.

Pel que fa a l'evolució del concepte, s'ha passat d'una visió més atomista del tòpic, com una entitat discreta vinculada al subjecte oracional i contraposada a la noció de focus o rema, a una concepció més clarament discursiva que accepta la possibilitat d'existència de més d'un tòpic en el discurs i relaciona el concepte amb les nocions d'informació pressuposada i de centre d'atenció. En aquest sentit, cal distingir el tòpic oracional del tòpic discursiu. Vegem-ho amb paraules de Belloro (2012):

El tópico oracional [...] es distinto del tópico (discursivo) que es posible generalizar a partir de una secuencia de oraciones que forman un texto coherente. El primero necesariamente corresponde a una expresión oracional, mientras que el segundo puede ser de naturaleza más abstracta. Existen, de hecho, razones para asumir que son objetos psicológicamente distintos. (p. 226)

L'anomenada contextualització interrogativa es fa servir sovint per explicitar l'articulació del tema i el rema oracional (per exemple, QUI ha vingut, al mu-

\footnotetext{
${ }^{2}$ Sobre la diversitat terminològica i altres qüestions relacionades amb la delimitació del mecanisme d'encapsulació en el conjunt de les relacions cohesives i, concretament, entre els mecanismes de referència, dins dels procediments de cohesió lèxica, vg. Schmid (2000, pp. 10-12), Ribera (2008, p. 277), López Samaniego (2014, pp. 33-36) i la bibliografia que s'hi cita.
} 
seu [tema]? JOAN [rema]). A més, com explica Vallduví (2002, pp. 1249-1256), atès que el tema no aporta informació, no pot aparèixer en la matriu oracional, sinó que és elidit o dislocat als marges esquerre o dret. Pel que fa al tòpic o tòpics discursius, el nombre de vegades que una entitat referencial és represa anafòricament constitueix un bon indicador de la topicalitat de l'entitat (Ribera, 2012, p. 52).

Les propietats que defineixen els encapsuladors -la reclassificació semàntica, la capacitat fòrica i la recategorització del contingut encapsulat- els situen en les zones d'intersecció entre el tòpic oracional i el discursiu, d'una banda, i entre el tòpic i el focus oracional, de l'altra. Vegem-ne un exemple:

(3) després ja discutirem a quin vagó va cadascú i a quina velocitat anem, però_abans hem de situar de nou el tren en el seu carril, perquè altrament no hi haurà ni trajecte,

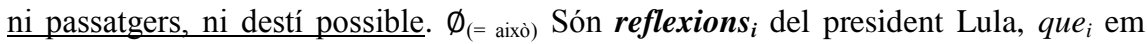
semblen oportunes per la $\operatorname{seva}_{i}$ lucidesa i sentit comú. (Investidura, Mas, CiU, 61)

Observem que l'encapsulador reflexions, gràcies a la capacitat conceptualitzadora que posseeix, converteix en tòpic discursiu la informació encapsulada: la represa subsegüent mitjançant el relatiu i el possessiu ho corroboren. Tanmateix, l'estructura atributiva adscriptiva, amb el demostratiu neutre elidit com a tòpic oracional, marca l'encapsulador com a predicació caracteritzadora que constitueix el focus de l'oració en què s'insereix. A més, considerant la reclassificació semàntica que opera sobre l'antecedent, comporta una informació cognitivament nova; en aquest sentit, no endebades López Samaniego (2013) concep els encapsuladors com a mecanisme en què s'entrecreuen dues operacions discursives i cognitives: la represa fòrica del referent i la construcció d'un referent nou.

A continuació, amb els conceptes de tòpic, focus i centre d'atenció, ens ocupem de l'encapsulació com a índex que permet explicitar l'estructura informativa de DP.

\subsection{ELS ENCAPSULADORS I L'ESTRUCTURA INFORMATIVA}

Com hem avançat, la reïficació de les entitats predicatives encapsulades permet la integració conceptual del discurs ("conceptual integrating", vg. Schmid, 2000, pp. 370-376), de manera que els predicats encapsulats emergeixen com una espècie de fites textuals ("signposting", vg. Schmid, 2000, pp. 349-359) que poden ser topicalitzades o focalitzades. Vegem-ho amb un exemple complex que, per l'acumulació d'encapsuladors, és ben representatiu':

\footnotetext{
${ }^{3}$ Aquest exemple procedeix del Debat general sobre la sentència del Tribunal Constitucional sobre l'Estatut (VIII legislatura, vuitè període, sessió núm. 84,16 de juliol de 2010).
} 
(4) [...] crec que l'eslògan (1) era un altre; el clam (1) més escoltat, el 10 de juliol, era [ "independència” (1)] (2)

I nosaltres serem coherents en aquesta línia (2), per tres raons (3): la primera

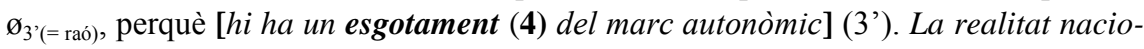
nal de Catalunya no cap en el marc constitucional espanyol (4).

En segon lloc, perquè [hi ha una manca de voluntat (5), per part de l'Estat espanyol, per reconèixer la plurinacionalitat (5)] (3'). Miri, dit clarament, perquè ens entengui tothom, a Espanya només ens hi volen de genolls i pagant. Ho va dir el senyor Mariano Rajoy, diu: "El que han de fer els catalans és treballar i pagar impostos". I em fa l'efecte que això expressa molt bé el que pensen alguns de Catalunya. A nosaltres, ens hi volen de genolls $i$ pagant (6), i em fa l'efecte que $\emptyset_{6}(=$ això) $j$ ja no és només un problema (6) de dignitat, $\varnothing_{6(=\text { això) }}$ és un problema (6) també de supervivència com a poble.

I, en tercer lloc, perquè [nosaltres considerem que aquest Parlament ha d'iniciar la transició política cap a la independència per constituir un estat propi en el si de la Unió Europea, mitjançant un referèndum per la independència d'aquest país (7)] (3'"'). Creiem que aquest $\varnothing_{7 \text { (= full de ruta) }}$ és el full de ruta (7), no n'hi ha cap altre $\varnothing_{7 \text { (= full de ruta). }}$. Sabem que $\varnothing_{7}$ és una decisió (8) arriscada, com tot, aquesta vida es nodreix i s'omple de decisions arriscades. (Sentència TC, Puigcercós, ERC, 23)

Observem que el fragment conté vuit encapsuladors que s'entrellacen i s'imbriquen uns amb els altres per teixir una estructura informativa complexa:

1. L'emissor, el portaveu d'ERC (Joan Puigcercós), comença parlant de la manifestació del 10 de juliol de 2010 a Barcelona contra la sentència del Tribunal Constitucional, el tema del debat. L'encapsulador clam es constitueix en tòpic que avança catafòricament un acte il·locutiu: "independència”, el crit més corejat pels manifestants, que es converteix en focus informatiu. De fet, el clam és coreferent amb un encapsulador previ (l'eslògan), cosa que el converteix en el centre d'atenció de l'enunciat i en demostra el caràcter temàtic.

2. El clam d" "independència" és reprès anafòricament pel sintagma aquesta línia, que el reclassifica semànticament com un acte de pensament o declaració d'intencions: la línia d'actuació d'Esquerra Republicana. La definitud que li atorga el demostratiu permet interpretar-lo com a tòpic discursiu. Tanmateix, la reclassificació fa possible que alhora es pugui considerar com a focus oracional (ja que se situa al final de l'oració) i textual: malgrat que constitueixi una informació discursivament coneguda (discourse-given), per al receptor es tracta d'una entitat cognitivament nova (hearer-new; vg. Prince, 1981).

3. A continuació, l'orador avança catafòricament, com a part del focus anterior, tres raons que justifiquen la línia d'actuació; el sintagma preposicional es presenta prosòdicament com un enunciat amb entitat pròpia, que a partir d'aquest punt s'erigeix en un nou tòpic discursiu, actualitzat com 
a tal pels continguts encapsulats subsegüents: 3') hi ha un esgotament del marc autonòmic; 3') hi ha una manca de voluntat, per part de l'Estat espanyol, per reconèixer la plurinacionalitat; i 3"') nosaltres considerem que aquest Parlament ha d'iniciar la transició política cap a la independència per constituir un estat propi en el si de la Unió Europea. De fet, no hi ha cap altra entitat que hi pugui competir com a tòpic: el sintagma per tres raons constitueix un enunciat monocèntric i l'el-lipsi posterior (la primera $\varnothing_{3^{\prime}(=\text { raó) }}$ ) el confirma com a tòpic.

4. Cadascuna d'aquestes tres raons és explicada per mitjà d'un o més encapsuladors que actuen en l'àmbit de la coherència local. Així, la primera raó es focalitza en un esgotament ("del marc autonòmic") que avança catafòricament l'oració subsegüent: La realitat nacional de Catalunya no cap en el marc constitucional espanyol. Aquest contingut encapsulat constitueix una mena de raó de l'estat de la situació que denota l'encapsulador esgotament. En el marc de l'estructura presentacional, esgotament és introduït com a focus oracional i actualitzat com a tòpic local pel contingut encapsulat subsegüent.

5. La segona raó es focalitza en una manca de voluntat, que òbviament introdueix la idea (objecte de pensament) de la negativa dels oponents polítics a reconèixer la plurinacionalitat (de l'Estat espanyol). La situació és semblant al cas precedent: manca de voluntat és el focus de l'estructura presentacional $\mathrm{i}$, una vegada introduït, es converteix en el tòpic que es desenvolupa en la resta del paràgraf.

6. Aquesta segona raó o argument que justifica el "clam" d'independència i la "línia" d'actuació que presenta Puigcercós és amplificada, per contrast, amb el que, segons l'orador, pretenen els rivals polítics: A nosaltres, ens $h i$ volen de genolls $i$ pagant. Aquesta informació es constitueix en el nou tòpic discursiu (mitjançant les construccions atributives de subjecte el-líptic) i es reclassifica com un doble problema ("de dignitat" i "de supervivència com a poble"), que esdevé un nou focus informatiu.

7. Seguidament, l'orador introdueix la tercera raó (nosaltres considerem que aquest Parlament [...]), recategoritzada metafòricament com a full de ruta, un objecte de pensament que comporta tota una declaració d'intencions de l'activitat futura d'Esquerra Republicana. El caràcter emfàtic de l'estructura atributiva especificadora ("Aquest és el full de ruta") situa el referent com a focus contrastiu i la clàusula subsegüent ("no n'hi ha cap altre $\varnothing_{7(=\text { full de ruta) }}$ ") així ho corrobora. Les dues elisions posteriors de l'encapsulador mostren el caràcter de tòpic local que assoleix l'entitat.

8. Finalment, el "full de ruta" és reclassificat com a decisió, una nova entitat mental de caràcter volitiu, que es constitueix en nou focus. 


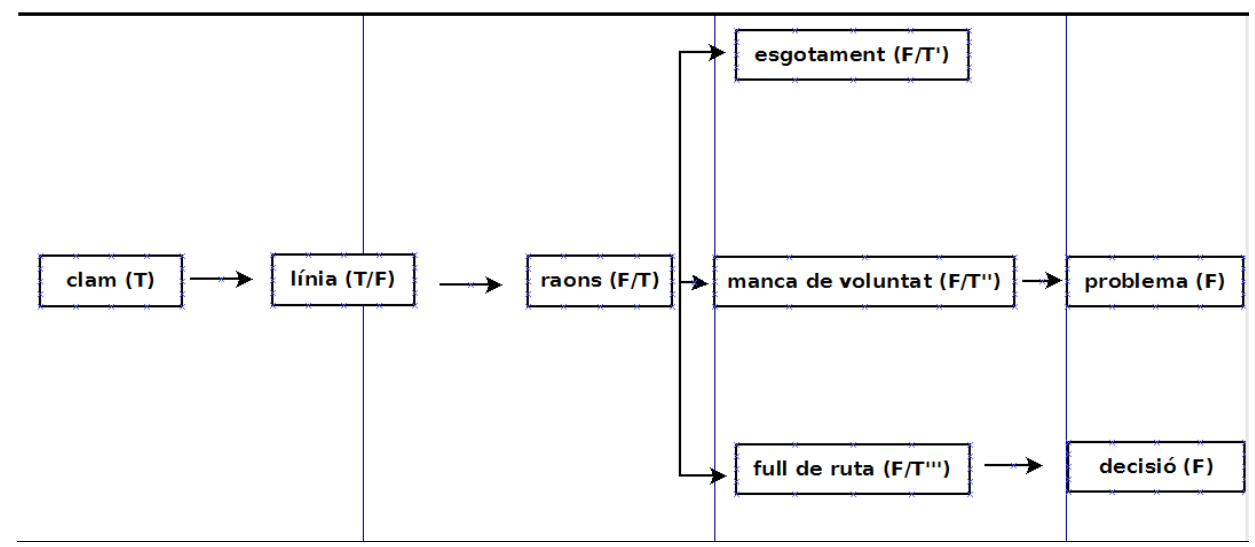

Gràfic 3. Encapsulació i estructura informativa de l'exemple (4)

En síntesi, interessa remarcar com la cadena de mecanismes encapsuladors permet visualitzar l'estructura conceptual i informativa del fragment, construit sobre la base d'una sèrie d'informacions que van actualitzant-se com a focus i com a tòpics per dissenyar un potent artefacte argumentatiu (vg. el gràfic 3). De fet, la capacitat fòrica i resumitiva que posseeixen aquest noms permet destacar els assumptes que centren la discussió dels participants en el debat. En altres paraules, com a mecanismes que expliciten la cohesió i avaluen la informació, els encapsuladors presenten una funció persuasiva, atès que generen un efecte intrínsec de repetició $i$, doncs, d'insistència en els assumptes del debat. D'aquesta manera, els encapsuladors es vinculen a les metafuncions textual i interpersonal de Halliday (1994), perfilant, d'una banda, l'estructura textual i fent palesa, d'altra banda, la interacció entre els participants.

En l'apartat següent ens ocupem dels principals patrons lexicogramaticals i discursius en què s'insereixen els encapsuladors, i dels efectes que provoquen en l'estructura informativa.

\section{PATRONS D'ÚS DELS ENCAPSULADORS EN EL DP}

El fet que els noms encapsuladors no són un tipus paradigmàtic de noms, sinó "an open-ended functionally defined class" (Schmid, 2000, p. 4) o una funció discursiva, usant paraules de López Samaniego (2014, p. 189), constitueix un indicador prominent de la importància de l'entorn funcional, sintàctic i discursiu. Així, Schmid (2000) parteix d'una sèrie d'estructures sintàctiques privilegiades en què poden aparèixer els encapsuladors (bàsicament el patró completiu $\mathrm{N} \mathrm{Cl}$ 
i l'atributiu $\mathrm{N}$ be $\mathrm{Cl}$ ) a l'hora de determinar quins noms són uns bons candidats per ser shell nouns (Schmid, 2000, § 3.1.1).

Seguint López Samaniego (2014, pp. 189-265), hem distingit entre patrons lexicogramaticals i discursius. En el primer cas, ens referim a una sèrie de construccions sintàctiques oracionals recurrents en què s'insereixen l'encapsulador i sovint també el contingut encapsulat; en canvi, els patrons discursius representen mecanismes d'encapsulació d'abast interoracional.

No és la nostra intenció descriure exhaustivament tots els tipus i subtipus de patrons identificats en el DP, sinó que ens limitem a caracteritzar aquells que presenten una major freqüència d'ús $i$, per tant, tenen una major incidència en la estructura informativa dels debats. En aquest sentit, hem identificat dos patrons discursius generals, un d'anafòric i un de catafòric, i tres de lexicogramaticals (atributiu focalitzador, atributiu tematitzador i completiu). Els discutim tot seguit.

\subsection{EL PATRÓ GENERAL DISCURSIU ANAFÒRIC}

El patró general anafòric, constituït habitualment per un sintagma amb demostratiu o article definit, és el que té una funció més clarament cohesiva, ja que la represa anafòrica del fragment textual encapsulat és el tret discursiu més prominent, com s'observa en els exemples següents:

(5a) en l'escenari nacional planta cara, però en l'escenari econòmic el que fa és acatar [...] Quin és el millor actiu per canviar aquesta ambició intermitent? (Investidura, Herrera, ICV-EUiA, 277)

(5b) Hablando de este proceso de aprobación estatutaria y de la situación que se provoca cuando unos ciudadanos votan un estatuto que luego el Tribunal Constitucional declara inconstitucional, dije literalmente: La consecuencia de este desdichado procedimiento - que lo es - es que muchos catalanes sienten que sus aspiraciones no caben en la Constitución. (Congreso, Rubalcaba, PSOE, 197)

(5c) why does the First Minister want Scotland to languish for another year and a half before we get the chance to vote on that? The truth behind the delay is not that the First Minister is holding to a promise that was made to the electorate in a television debate. (Sct P, Johann Lamont, Glasgow Pollok, Lab, 28)

En (5a) i (5b) és palesa la funció cohesiva del mecanisme d'encapsulació, encara més destacada per la força díctica textual del demostratiu. Amb tot, la cohesió encapsuladora també s'estableix mitjançat l'article definit (5c).

D'altra banda, els exemples de (5) mostren la versatilitat del patró des del punt de vista de l'estructura informativa. En (5a) el sintagma encapsulador aquesta ambició és part del focus oracional; a més, el caràcter semànticament marcat del substantiu ambició i de l'adjectiu intermitent introdueixen el punt de vista 
irònic de l'emissor, que construeix un nou referent, cosa que remarca el caràcter focal de la informació; tanmateix, el valor ostensivament anafòric marcat pel demostratiu hi confereix també topicalitat discursiva. En (5b) i en (5c), en canvi, els encapsuladors són part del tòpic oracional i el caràcter d'informació coneguda és destacat per la major afinitat semàntica entre els noms i una part dels continguts encapsulats (procedimiento = proceso ; delay $=$ languish for another year and a half), un tret essencial en el cas de (5c), que compensa la força cohesiva menor de l'article definit en contrast amb el demostratiu'.

\subsection{EL PATRÓ GENERAL DISCURSIU CATAFÒRIC}

El patró general catafòric més freqüent es basa en un sintagma indefinit o quantificat que constitueix el focus d'un predicat presentacional i alhora estableix com a assumpte del discurs el contingut predicatiu subsegüent.

(6a) Sí que hi ha alternatives, senyor president [...] Les $\emptyset_{(=\text {alternatives })}$ que no costen un sol euro: la moratòria dels desnonaments [...] és hora de repartir el treball [...] N'hi ha d'altres $\emptyset_{(=\text {alternatives })}[\ldots]$ Una $\emptyset_{(=\text {alternativa })}$, molt senzilla [...] ja està bé de pagar llicències a Microsoft Word. (Investidura, Fernàndez, CUP, 390)

(6b) [...] usted nos ha introducido hoy importantes falacias. La $\emptyset_{(=\text {falacia) }}$ más importante de todas es confundir el método con el resultado, el derecho a decidir la democracia con el resultado. (Congreso, Coscubiela, Izquierda Plural, 273)

(6c) There are two aspects to that important question. One is the responsibilities of the Electoral Commission regarding information about the ballot [...] The second aspect is the obligation on the two campaigns to present their arguments not just in an uplifting and positive way. (Sct P, Alex Salmond, First Minister, SNP, 73)

Observem que els tres exemples de (6) mostren sintagmes indefinits situats en la part remàtica de l'oració, en (6a) i en (6c) dins de l'àmbit d'una estructura presentacional amb haver-hi / there-be. En (6b) l'estructura no és sintàcticament presentacional, però semànticament i pragmàtica s'hi assembla molt. En els tres casos, una vegada presentat com a focus, l'encapsulador catafòric és successivament reprès com a tòpic, per les elisions de (6a) i (6b) i pel pronom indefinit one i la repetició posterior en (6c), de manera que, en el moment en què apareix el contingut encapsulat, aquest ja constitueix el tema o assumpte del debat.

\footnotetext{
${ }^{4}$ Discutir les condicions que determinen que l'encapsulador sigui especificat per l'article definit o pel demostratiu supera els límits d'aquest treball. Afegirem, però, que la major afinitat semàntica entre l'encapsulador i el contingut encapsulat afavoreix el recurs a l'article; en canvi, el demostratiu, amb funció de díctic textual, permet establir la relació fòrica de manera més explicita, fins i tot quan la relació semàntica entre les dues unitats és poc clara.
} 


\subsection{EL PATRÓ ATRIBUTIU FOCALITZADOR $(S E R / B E N)$}

Aquest patró lexicogramatical consisteix en una construcció atributiva en què el sintagma encapsulador ocupa la posició d'atribut $i$, doncs, constitueix el focus oracional.

(7a) Cal recuperar el model de la Barcelona i la Catalunya dels Jocs Olímpics i cal, senyor president, recuperar aquest prestigi, al marge dels debats estèrils. Això ja va passar, i no hi ha motius perquè ara no ho intentem. $\emptyset_{(=\text {això) }}$ És la seva responsabilitat. (Investidura, Herrera, PSC, 203)

(7b) [...] no reconocer otra autoridad por encima de los ciudadanos que la de la ley; eso es la democracia. (Congreso, Rajoy, PP, 133)

(7c) The figure has fluctuated over a 32 -year period between $£ 12$ billion at the highest and $£ 1$ billion at the lowest. That is enormous volatility ${ }_{i}$ and $i t_{i}$ is far more than "alleged". (Sct IR, Gavin Brown, Lothian, Con, 428)

En (7a) els pronoms neutres ho i això i el subjecte el·líptic estableixen una cadena de coreferència que reprèn com a tòpic el contingut de la primera oració; després, el substantiu modal deòntic responsabilitat, que enllaça amb el contingut també modal de l'antecedent, reconstrueix el referent des de la perspectiva intersubjectiva de l'emissor i hi focalitza l'atenció informativa. En (7b) i en (7c) les estructures atributives són completament focals; de fet, marquen sengles focus contrastius. Tanmateix, en (7c) l'atribut és caracteritzador i, doncs, se'n podria qüestionar el valor anafòric $\mathrm{i}$ encapsulador, tot $\mathrm{i}$ que el pronom it subsegüent, coreferent amb enormous volatility, reafirma el valor referencial de l'entitat i, de fet, la marca com a tòpic 5 .

\subsection{EL PATRÓ ATRIBUTIU TEMATITZADOR ( $N$ SER/BE CL)}

Aquest patró inverteix l'estructura informativa de l'atributiu focalitzador.

(8a) el repte principal és capgirar les polítiques econòmiques. (Investidura, Herrera, IC, 287)

(8b) Empezamos a pensar que su objetivo es mantener una Constitución trampa, una especie de cárcel de los pueblos. (Congreso, Esteban, PNV, 411)

(8c) the SNP's big plan for corporation tax used to be that it would take it down to 20 per cent to make us more competitive. (Sct P, Gavin Brown, Lothian, Con, 224)

Observem que ara l'encapsulador ocupa la posició del tòpic oracional i efectua la tematització de la clàusula encapsulada, que és l'atribut focal.

${ }^{5}$ Un subtipus específic d'aquest patró és aquell en què la clàusula encapsulada constitueix el tema de la construcció atributiva i, per tant, l'encapsulador en focalitza directament el referent. 


\subsection{EL PATRÓ LEXICOGRAMATICAL COMPLETIU ( $N C L)$}

El patró completiu constitueix una construcció sintagmàtica amb una clàusula substantiva completiva amb que / that o d'infinitiu, com en (9).

(9a) molts dels que estem aquí tenim l'aspiració que Catalunya sigui un nou estat d'Europa. (Investidura, Junqueras, ERC, 141)

(9b) tenemos la obligación de tener argumentos y de ser capaces de defender una tesis y la contraria en función del cuál sea el cliente. (Congreso, Duran, CiU, 249)

(9c) Ruth Davidson's argument that independence is a departure from the progress of national self-determination does not hold water when it is examined. (Sct. P, Alex Salmond, First Minister, SNP, 47)

En aquest cas, resulta evident que l'encapsulador serveix per topicalitzar, ni que sigui en l'àmbit local del sintagma, el contingut de la clàusula. A més, però, el conjunt de la construcció pot constituir el focus informatiu-com en (9a) i (9b) - o el tòpic - en (9c) - en funció de la posició que ocupi en l'oració en què s'insereix.

\section{ANÀLISI CONTRASTIVA DELS PATRONS D'ÚS DELS ENCAPSULADORS}

Contrastivament, les dades quantitatives que hem obtingut per a cada patró mostren un comportament dels encapsuladors bastant homogeni en cadascuna de les llengües, amb lleugeres diferències (vg. taula 2).

El català i l'espanyol apunten tendències més semblants, cosa que es pot atribuir a la major similitud retòrica i estilística dels debats, que, com hem dit, constitueixen una sèrie de monòlegs superposats. De fet, el grau de coincidència

Taula 2. Patrons d'ús dels encapsuladors en el DP

\begin{tabular}{|l|r|r|r|r|r|c|}
\hline \multirow{2}{*}{ Patrons d'ús } & \multicolumn{2}{c|}{ Català } & \multicolumn{2}{c|}{ Espanyol } & \multicolumn{2}{c|}{ Anglès } \\
\cline { 2 - 7 } & núm. & $\%$ & núm. & $\%$ & núm. & $\%$ \\
\hline general anafòric & 117 & 0,2811 & 130 & 0,2556 & 128 & 0,4338 \\
\hline general catafòric & 152 & 0,3652 & 114 & 0,2242 & 72 & 0,2440 \\
\hline atributiu focalitzador $(\operatorname{ser} \mathrm{N})$ & 59 & 0,1417 & 70 & 0,1376 & 52 & 0,1762 \\
\hline atributiu tematitzador $(\mathrm{N}$ ser $\mathrm{Cl})$ & 42 & 0,1009 & 36 & 0,0708 & 55 & 0,1864 \\
\hline oracional completiu $(\mathrm{N} \mathrm{Cl})$ & 83 & 0,1994 & 120 & 0,2360 & 150 & 0,5084 \\
\hline altres & 12 & 0,0288 & 10 & 0,0197 & 15 & 0,0508 \\
\hline TOTAL & 465 & 1,1171 & 480 & 0,9439 & 472 & 1,5996 \\
\hline
\end{tabular}


de les freqüències de cada patró és més alt que en anglès, tot i que en català predomina clarament el patró general catafòric $(0,3652 \%)$, mentre que en espanyol ho fa el general anafòric $(0,2556 \%)^{6}$.

Les freqüències elevades del patró general anafòric en les tres llengües, sobretot en anglès $(0,4372 \%)$, són un indicador del grau de cohesió del DP: estem al davant d'un gènere informativament dens, que necessita una articulació ben travada i la represa reiterada del fil conductor de l'oral.

En canvi, la catàfora, com a mecanisme referencial discursivament marcat, es pot considerar un indicador de la intenció argumentativa inherent al DP: contribueix a crear unes expectatives en el receptor que l'obliguen a escoltar el discurs subsegüent; de fet, serveix per cridar l'atenció dels participants sobre allò que s'està a punt de dir. En aquest sentit, el patró general catafòric opera sobretot en el nivell de la macroestructura, de manera que es pot afirmar, si més no, que el debat en català presenta un discurs més planificat i estructurat, orientat a guiar explícitament el receptor. Els debats en espanyol i en anglès també ho fan: les freqüències elevades del patró general catafòric així ho mostren; però de manera menys evident que el debat català.

El patró atributiu focalitzador també es relaciona amb la tipologia argumentativa del gènere. Aquesta construcció mostra unes freqüències remarcables en les tres llengües (al voltant del 0,15\%), amb un predomini de les estructures de focus contrastiu, més evident en català i en espanyol: com que es tracta de llengües de subjecte nul, la presència de demostratius en comptes de subjectes elidits és un indicador sintàctic del focus contrastiu.

En anglès la construcció també és freqüent, però l'obligatorietat del subjecte n'atenua el valor contrastiu, que s'ha de marcar mitjançant l'èmfasi. De fet, la freqüència lleugerament més elevada del patró atributiu tematitzador en anglès es pot relacionar també amb l'especificitat sintàctica de l'anglès, com a llengua de subjecte ple.

Finalment, els valors molt més alts del patró completiu en anglès $(0,5084 \%)$ apunten cap al grau de gramaticalització de la construcció, amb la freqüència d'estructures com the fact/point/argument that-Clo the ability/opportunity to-Cl. Sembla que el patró completiu emergeix com a molt específic del DP en anglès, malgrat que també té valors remarcables en català i en espanyol: l'afavoreix la funció que acompleix d'establiment de tòpics en el nivell local.

El gràfic 4 permet copsar el comportament molt homogeni dels encapsuladors en les tres llengües a l'hora de delimitar l'estructura informativa del DP. Aquesta homogeneïtat interlingüística dels patrons lexicogramaticals i discursius $s$ 'ha d'atribuir al gènere textual.

\footnotetext{
${ }^{6}$ En la categoria altres s'inclouen diversos patrons anafòrics i catafòrics alhora, que, per raons d'espai, no analitzem en aquest treball.
} 


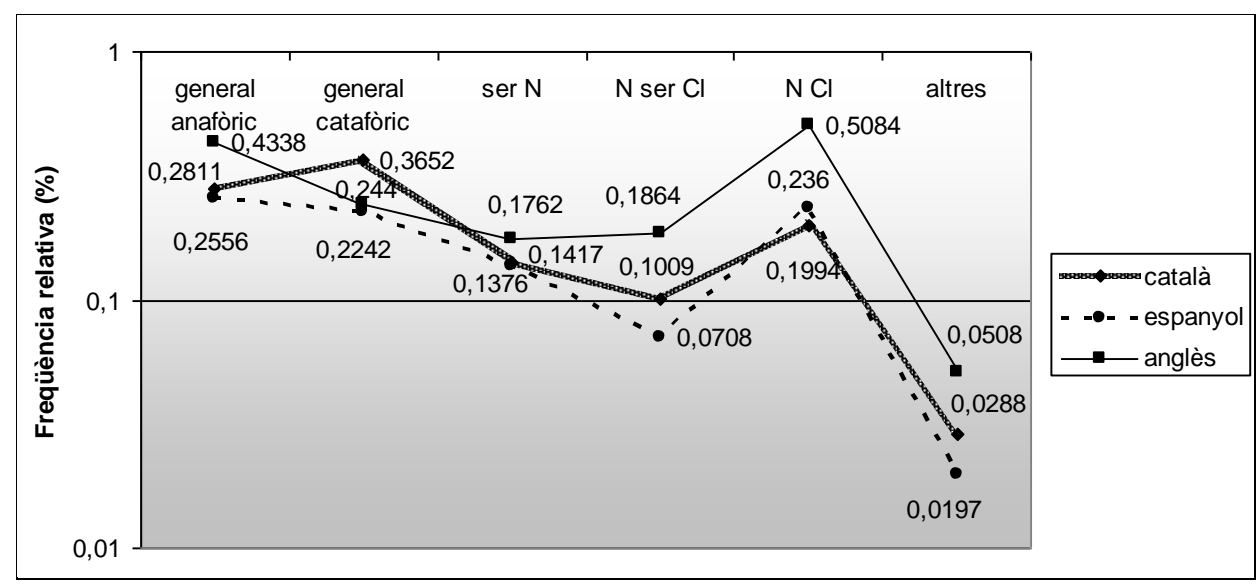

Gràfic 4. Patrons d'ús dels encapsuladors en el DP

\section{CONCLUSIONS}

Al llarg d'aquest treball hem descrit la contribució de l'encapsulació lèxica a la delimitació de l'estructura informativa del DP, en l'àmbit del discurs polític. La freqüència elevada d'encapsuladors constitueix un indicador de la densitat cohesiva i informativa del gènere.

Estadísticament, el debat escocès presenta una major densitat encapsuladora, cosa que es pot relacionar amb un estil més intervencionista per part dels oradors, que orienten el receptor fent molt explícita l'estructura retòrica del discurs. En català i en espanyol la densitat encapsuladora és menor, però gens menyspreable, de manera que la funció persuasiva és també ben palesa.

Les propietats definitòries del mecanisme -la conceptualització semàntica, la funció cohesiva fòrica i la recategorització cognitiva- li confereixen les característiques idònies per constituir l'eix sobre el qual pivota l'estructura del DP. En aquest sentit, la reïficació que operen els encapsuladors sobre els continguts encapsulats es revela com el tret que permet la delimitació dels temes dels debats. D'altra banda, la singularitat que posseeixen com a mecanisme de represa de fragments discursius complexos de naturalesa predicativa permet la integració conceptual del DP. Al seu torn, la recategorització sintàctica i cognitiva del contingut encapsulat activa la construcció de referents nous a partir de la reavaluació d'informacions discursivament conegudes. Aquestes operacions d'explicitació de l'estructura retòrica i d'avaluació dels continguts encapsulats vinculen el mecanisme a la dinàmica argumentativa del DP $\mathrm{i}$ a les metafuncions textual i interpersonal definides per Halliday (1994). 
La recategorització cognitiva dels referents, combinada amb la versatilitat sintàctica que mostren aquests noms inespecífics en diversos patrons lexicogramaticals i discursius, els permet funcionar de manera simultània o successiva com a tòpics i com a focus. Així, els diferents patrons mostren la interacció, des del punt de vista de l'estructura informativa, entre el nivell oracional i el nivell textual, entre la microestructura i la macroestructura.

Pel que fa als patrons específics, el general catafòric i l'atributiu focalitzador es vinculen directament amb la tipologia argumentativa del DP. La freqüència més elevada en català del patró catàfòric contribueix en bona mesura a marcar més encara l'estructura argumentativa del debat; de fet, el caràcter marcat de la catàfora compensa la menor densitat encapsuladora respecte al debat escocès. D'altra banda, la freqüència molt més elevada del patró completiu en anglès sembla apuntar cap a processos de gramaticalització més marcats en relació amb aquesta construcció sintàctica. Finalment, s'ha observat un comportament interlingüístic molt homogeni dels diversos patrons d'ús, cosa que cal atribuir al caràcter ritualitzat $i$ altament formalitzat del gènere.

\section{AGRAÏMENTS}

Aquest treball s'insereix en el projecte de recerca Gramàtica, pragmàtica $i$ interacció multimodal (GRAMPINT, FFI2014-56258-P), finançat pel Ministerio de Economía y Competitividad del Gobierno de Espanya. Volem agrair al Dr. Jesús Jiménez l'elaboració dels tests estadístics. També cal agrair els comentaris de la Dra. Maria Josep Marín i de dos avaluadors anònims, que han contribuït a millorar la recerca. 


\section{BIBLIOGRAFIA}

Belloro, V. (2012). La estructura informativa. Dins R. Mairal, L. Guerrero \& C. González Vergara (Coords.), El funcionalismo en la teoría lingüística: la Gramàtica del Papel y la Referencia (pp. 225-244). Madrid: Akal.

Bolinger, D. (1952). Linear modification. Publications of the Modern Language Association of America, 67, 1117-1144.

— (1954). Meaningful word order in Spanish. Boletín de Filología (Universidad de Chile), VIII, 45-56.

Borreguero Zuloaga, M. (2006). Naturaleza y función de los encapsuladores en los textos informativamente densos (la noticia periodística). Cuadernos de Filología Italiana, 13, 73-95.

Cuenca, M. J. (2000). Estudi estilístic i contrastiu de l'arquitectura de l'oració. Estil segmentat vs. estil cohesionat. Caplletra, 29, 105-120.

- (2014). The use of demonstratives and context activation in Catalan parliamentary debate. Discourse Studies, 16 (6), 729-752. DOI: 10.1177/1461445614546258.

Dijk T. A. van (2000). Parliamentary Discourse. Dins R. Wodak \& T. A. van Dijk (Eds.), Racism at the Top. Parliamentary Discourses on Ethnic Issues in Six European States (pp. 45-78). Klagenfurt: Drava.

Firbas, J. (1966a). On defining the theme in functional sentence analysis. Travaux Linguistiques de Prague, 1, 267-280.

- (1966b). Non-thematic subjects in contemporary English. Travaux Linguistiques de Prague, 2, 239-256.

Givón, T. (1983). Topic continuity in discourse: an introduction. Dins T. Givón (Ed.), Topic Continuity in Discourse (pp. 1-41). Amsterdam: John Benjamins.

Halliday, M. A. K. (1994). An Introduction to Functional Grammar. London: Edward Arnolds.

Halliday, M. A. K \& Hasan, R. (1976). Cohesion in English. London \& New York: Longman.

Ilie, C. (2006). Parliamentary Discourses. Dins K. Brown (Ed.), Encyclopedia of Language and Linguistics, 2nd Edition. Vol. 9 (pp. 188-197). Oxford: Elsevier.

Institut d'Estudis Catalans (2007). Diccionari de la llengua catalana. Segona edició (DIEC2). Obtingut de http://dlc.iec.cat/.

Jansen, H. (2003). Densità informativa. Tre parametri linguistico-testuali. Uno studio contrastivo inter- ed intralinguistico. Copenhagen: Museum Tusculanum.

Langacker, R. W. (1987). Foundations of Cognitive Grammar, vol. I: Theoretical Prerequisites. Stanford: Stanford University Press.

López Samaniego, A. (2011). La categorización de entidades del discurso en la escritura profesional. Las etiquetas discursivas como mecanismo de cohesión léxica (tesi doctoral). Barcelona: Universitat de Barcelona. Obtingut de http://hdl.handle.net/10803/48757.

- (2013). Las etiquetas discursivas: del mantenimiento a la construcción del referente. Estudios de Lingüistica, 27, 167-197.

- (2014). Las etiquetas discursivas: cohesión anafórica y categorización de entidades del discurso. Pamplona: EUNSA.

Prince, E. F. (1981). Toward a taxonomy of given-new information. Dins P. Cole (Ed.), Radical Pragmatics (pp. 223-255). New York: Academic Press.

Ribera, J. (2008). La cohesió lèxica en seqüències narratives (tesi doctoral). València: Universitat de València. Obtingut de http://www.tesisenxarxa.net/TDX-0917109-143808/index.html

- (2012). La cohesió lèxica en seqüències narratives. Alacant \& Barcelona: IIFV \& PAM.

Ribera, J. \& Marín, M. J. (en premsa). Objectivizing and subjectivizing encapsulation as evaluative strategies in parliamentary debate. Dins M. Díez Prados \& A. García Gómez (Eds.), Exploring evaluative and persuasive strategies in discourse. Amsterdam: John Benjamins. 
Salvador, V. (2000). L'estil nominalitzat. Caplletra, 29, 69-82.

Schmid, H.-J. (2000). English Abstract Nouns as Conceptual Shells. From Corpus to Cognition. Berlin: Mouton De Gruyter.

Serafini, T. (1992). Come si scrive. Milano: Fabbri-Bompiani.

Vallduví, E. (2002). L’oració com a unitat informativa. Dins J. Solà, M. R. Lloret, J. Mascaró \& M. Pérez-Saldanya (Dirs.), Gramàtica del català contemporani (pp. 1221-1279). Barcelona: Empúries. 